PROFESI (Profesional Islam)

Media Publikasi Penelitian; 2017; Volume 15; No 1.

Website: ejournal.stikespku.ac.id

\title{
Studi Pemanfaatan Posyandu Lansia dan Evaluasi Penggunaan KMS di Sukoharjo
}

\author{
Indarwati $^{1^{*}}$, Kustanti ${ }^{2}$. Sri Dayaningsih ${ }^{3}$ \\ ${ }^{1}$ Prodi Keperawatan STIKES Aisyiyah Surakarta \\ ${ }^{2}$ Prodi Keperawatan Politeknik Bhakti Mulia Sukoharjo \\ ${ }^{3}$ Prodi Keperawatan Politeknik Bhakti Mulia Sukoharjo \\ indarstikes@gmail.com.
}

Kata Kunci
Posyandu Lansia,
Peran kader,
KMS

\begin{abstract}
Abstrak
Kemenkes RI 2014 menyebutkan usia lansia sebesar 12.740.265 jiwa, sehingga angka beban tanggungan menjadi sangat tinggi yaitu 51,3 dan sasaran usia berresiko tinggi akan menjadi lebih besar. Besarnya jumlah penduduk beresiko tersebut menjadi beban tersendiri bagi pemerintah. Di jawa tengah layanan kesehatan penduduk usia lansia tahun 2012 masih rendah (53.83\%), artinya propinsi Jawa Tengah belum memperhatikan pelayanan kesehatan untuk kelompok pra usila dan usila. di Sukoharjo, Pelaksanaan kegiatan posyandu sebagai satu wadah pelayanan kesehatan secara swadana dari masyarakat masih monoton yaitu menimbang berat badan, ukur tekanan darah dan senam lansi. Penelitian ini bertujuan mendesekripsikan pelaksanaan posyandu lansia, keaktifan lansia dan peran kader lansia dalam menggerakkan masyarakat untuk aktif datang ke posyandu lansia. Metode penelitian ini meggunakan pendekatan kualitatif dilakukan untuk menjawab tujuan penelitian ini, informan kunci adalah bidan, tokoh masyarakat, kader dan lansia. Pengumpulan data dengan wawancara dan observasi langsung kegiatan posyandu. Hasil penelitian menunjukkan bahwa pelayanan posyandu tidak sesuai dengan prosedur lima meja. Namun prinsipnya pelayanan posyandu lansia telah memenuhi unsur lima layanan, lansia akfif dan senang di kegiatan posyandu dan peran kader sangat bagus dan kreatif. Sedangkan KMS belum dimanfaatkan secara optimal. Posyandu lansia tidak berjalan sesuai urutan lima meja, Lansia dan kader aktif dalam kegiatan posyandu, KMS belum difungsikan sebagaimana mestinya.
\end{abstract}

\section{Study of Posyandu Lansia Benefit And Evaluation of KMS Using In Sukoharjo}

\section{Keywords}

Elderly Posyandu, Cadres in posyandu, KMS

\begin{abstract}
Background, Indonesia Ministry of Health 2014 mentions the amount of elderly equal to 12,740,265 people. It makes the amount of dependent burden become very high 51,3 and the target of high risk age is higher. The high amount of high risk people becomes a burden for the government. In Central Java the health service of elderly people in 2012 was low (53.83\%), it means that Central Java province has not care yet about health service for pre-aged and elderly. In Sukoharjo the implementation of posyandu activities which is as an self-financed organization of health service is monotonous, the activity such as: weighting the body weight, measuring blood pressure and gymnastics. The study aims to describe the implementation of posyandu for elderly, of the elderly and the role of elderly-cadres to invite the society to come to elderlyposyandu actively. The research method was qualitative approach, was done to
\end{abstract}


PROFESI (Profesional Islam)

Media PublikasiPenelitian; 2017; Volume 15; No 1.

Website: ejournal@stikespku.ac.id

answer the aim of this research. The key informantion were midwives, society leaders, cadres and elderly. The data collection was by interview and direct observation of posyandu activities. The result showed posyandu service was not appropriate with the five table procedures. However, the principle of elderly service posyandu had fulfilled the five elements of service, active and happy in posyandu activities and the role of cadres was very good and creative. While KMS has not been used optimally. Conclusion, elderly Posyandu is not appropriate of five table procedures, Elderly and active cadres in posyandu activities, KMS has not functioned properly. Suggestion it is need to refresh the cadres of posyandu with five service table procedures as well as filling KMS.

\section{PENDAHULUAN}

Meningkatnya angka harapan hidup (life ecpectancy) merupakan salah satu indikator keberhasilan pembangunan kesehatan di Indonesia. Dilihat dari sisi ini pembangunan kesehatan di Indonesia sudah cukup berhasil, dengan indikator angka harapan hidupnya meningkat secara bermakna yaitu 69,65 di tahun 2011 menjadi 72 tahun di tahun 2012. Namun demikian angka harapan hidup yang meningkat ini justru membawa beban bagi masyarakat, karena populasi penduduk usia lanjut (lansia) yang meningkat ini mengakibatkan kelompok resiko dalam masyarakat menjadi lebih tinggi (Kemenkes, 2013).

Kemenkes RI 2014, menyebutkan bahwa usia lansia 65 tahun keatas sebesar 12.740.265, dengan demikian angka beban tanggungan menjadi sangat tinggi yaitu 51,3. Selanjutnya sasaran program kesehatan pada usia lanjut yang berresiko tinggi yaitu usia lebih dari 69 tahun adalah 7.735.410 jiwa. Besarnya jumlah penduduk lansia beresiko tersebut menjadi beban tersendiri yang perlu diperhatikan pemerintah.

Hasil penelusuran angka cakupan pelayanan kesehatan pada penduduk usia lansia di propinsi Jawa Tengah pada tahun 2012 terlaporkan masih rendah (53.83\%). Artinya propinsi Jawa Tengah belum memperhatikan pelayanan kesehatan untuk kelompok pra usila dan usila yang merupakan kelompok usia berisiko (Profile Dinkes Jateng, 2012)

Salah satu upaya pemerintah dalam memberikan pelayanan kesehatan kepada lansia adalah dengan mendorong, membina dan memfasilitasi masyarakat dalam pendirian posyandu lansia. Melalui posyandu lansia ini diharapkan dapat memberikan pelayanan kesehatan khususnya berkaitan dengan promotiv, preventiv, rehabilitative dan pelayanan konseling dengan baik, sehingga mengurangi beban pemerintah dalam hal pembangunan kesehatan.

Seperti yang dijelaskan Notoatmodjo (2007) tentang posyandu, bahwa Posyandu lansia merupakan wahana pelayanan bagi kaum lansia, yang dilakukam dari, oleh dan untuk kaum usila yang menitik beratkan pada pelayanan promotiv dan preventiv, tanpa mengabaikan upaya kurativ dan rehabilitative. Sementara menurut Pedoman Pengelolaan Kesehatan di Kelompok Usia Lanjut (Depkes RI, 2003), pelayanan kesehatan di kelompok usia lanjut meliputi pemeriksaan kesehatan fisik dan mental emosional. Kartu Menuju Sehat (KMS) usia lanjut sebagai alat pencatat dan pemantau untuk mengetahui lebih awal penyakit yang diderita (deteksi dini) atau ancaman masalah kesehatan yang dihadapi dan mencatat perkembangannya dalam Buku Pedoman Pemeliharaan Kesehatan (BPPK) usia lanjut atau catatan kondisi kesehatan yang lazim digunakan di Puskesmas.

Disamping pelayanan kesehatan, di Posyandu Lanjut Usia juga dapat diberikan pelayanan sosial, agama, pendidikan, ketrampilan, olah raga dan seni budaya serta pelayanan lain yang dibutuhkan para lanjut usia dalam rangka meningkatkan kualitas hidup melalui peningkatan kesehatan dan kesejahteraan mereka. Selain itu mereka dapat beraktifitas dan mengembangkan potensi diri.

Peserta posyandu lansia adalah mereka masyarakat yang dikategorikan lansia. Sedangkan Menurut WHO, yang termasuk katagori lansia, adalah mereka yang berusia 65 tahun ke atas (AS dan Eropa Barat). Sedangkan di negara-negara Asia, lansia adalah mereka yang berusia 60 tahun 
keatas. Pengkatagorian lebih detail dikemukakan oleh Darmanto et al (2015), yang membagi lansia menjadi young elderly (65-74 tahun) dan older elderly (75 tahun). Sementara di Indonesia, Alwi Dahlan (2014) menyatakan bahwa orang dikatakan lansia jika telah berumur di atas 60 tahun.

Berdasarkan hasil studi pendahuluan yang dilakukan peneliti terhadap 5 orang lansia di desa Jetis wilayah kerja puskesmas Sukoharjo menjelaskan bahwa, posyandu sudah berjalan dengan baik pesertanya banyak kurang lebih tujuh puluhan peserta, yang menarik posyandu tersebut pernah mengikuti lomba posyandu dan menang mendapatkan juara 1 tingkat propinsi. Peserta posyandu lansia bukan saja wanita akan tetapi ada juga peserta laki-laki, namun Pelaksanaan kegiatan posyandu masih monoton yaitu menimbang berat badan, ukur tekanan darah dan senam. jarang sekali ada tambahan pengetahuan tentang kesehatan, sehingga masih dirasa kurang.

Terkait dengan penggunaan KMS lansia, selama ini menggunakan KMS lansia hanya untuk mencatat berat badan, tekanan darah saja, jadi pemeriksaan lain seperti tingkat kemandirian, status mental, pemeriksaan lab belum pernah dilakukan.

Berdasarkan fenomena tersebut, peneliti tertarik untuk mempelajari:

1. Bagaimana pelaksanaan posyandu lansia di Sukoharjo?

2. Bagaimana keaktifan lansia dalam kegiatan posyandu?

3. Bagaimana peran kader lansia dalam menggerakkan masyarakat untuk aktif datang ke posyandu lansia?

4. Bagaimana penggunaan KMS lansia?

Penelitian ini penting dilakukan, untuk mengkaji bagaimana upaya masyarakat dalam menghidupkan kegiatan posyandu lansia agar menjadi satu tempat layanan kesehatan yang menarik dan terus berlanjut. Sehingga hasil pengkajian ini bisa menjadi satu dasar pengembangan posyandu lansia tersebut maupun di tempat lain.

Tujuan penelitian ini adalah untuk mendiskripsikan fenomena kegiatan posyandu lansia, keaktifan lansia dan peran kader serta evaluasi penggunaan KMS lansia di posyandu lansia Jetis Sukoharjo.

\section{METODE PENELITIAN}

Penelitian secara survey dengan pendekatan kualitatif dipilih untuk menjawab focus permasalahan tersebut. Pengumpulan data dilakukan dengan observasi langsung dan wawancara mendalam dengan kader posyandu lansia, lansia sebagai peserta posyandu, bidan sebagai penanggung jawab pelaksanaannya dan tokoh masyarakat setempat. Validasi data dilakukan dengan tri angulasi sumber. Penelitian ini dilakukan di desa Jetis wilayah kerja Puskesmas Sukoharjo. Analisa data dilakukan dengan dasar teori Mile\&Hubermen yaitu dengan tiga langkah 1) pengumpulan data dan mencatatnya secara objektif hasil pengamatan maupun wawancara dengan informan kunci 2) langkah reduksi data dan 3) penyajian data untuk menggambarkan keseluruhan data sesuai dengan focus penelitian.

\section{HASIL DAN PEMBAHASAN}

\subsection{Bagaimana Pelaksanaan Posyandu Lansia} di Sukoharjo?

Berdasarkan hasil wawancara terkait gambaran pelaksanaan posyandu lansia "Ngudi Waras" ditemukan bahwa urutan pelayanan posyandu tidak sesuai dengan prosedur lima meja seperti yang telah ditetapkan. Namun pada prinsipnya pelayanan posyandu lansia terdapat lima layanan, yaitu pendaftaran, penimbangan, pengukuran tekanan darah, pengobatan sederhana oleh bidan dan pemberian makanan tambahan (PMT). Selain itu ada kegiatan tambahan secara rutin yaitu senam dan pengajian, sedangkan kegiatan lain adalah piknik yang dilakukan setiap enam bulan sekali dan pemeriksaan laboratorium gratis enam bulan sekali.

Belum ada konseling kesehatan secara khusus pada lansia, sehingga lansia merasa kurang puas, Hal ini dikarenakan alasan keterbatasan sumber daya kader. Berikut kutipan hasil wawancara peneliti dengan beberapa informan kunci

\section{Informan 1 \\ Urutannya,didaftar dulu.....trus ditimbang, diukur tekanan darahnya.teruuuus senam riyen....ngaji ...lajeng makan bersama dan terakhir diberi obat bu bidan. Cuma makan bersamanya selang seling maksude jadual bulan ini ada, besuk tidak ada gituuh. penyuluhan kesehatan nggeh sok-sok mawon}


PROFESI (Profesional Islam)

Media PublikasiPenelitian; 2017; Volume 15; No 1.

Website: ejournal@stikespku.ac.id

yen selo....emm margi nggeh repot pesertane katah kok mbak...(Ny T, 64 Tahun)

\section{Informan 2}

Urutannya memang tidak bisa urut seperti lima meja kados diteori itu bu...karna pesertanya banyak.... terkadang kerepotan saya..........kadang dari pendaftaran. langsung ke saya ukur tekanan darah.. kasih obat... nanti nimbang dilanjutin kadernya.... trus lansia ikut senam, pengajian dan makan bersama tapi tidak selalu....penyuluhan nggeh kadang.....(Ny W, 35 Tahun)

\section{Informan 3}

.... diawali dari pendaftaran dikasih KMS.....trus nimbang berat badan,..trus pengajian.... trus ke bidan diukur tekanan darahnya dan dicatat hasilnya di KMS tadiii oleh kader...trus senam dan terakhir PMT... tapi selang seling..nek masak terus nggeh dananya habis....penyuluhan kesehatan jarang bu...penting mpun diprikso wau kalih bu bidan....entuk obat (Ny S, 49 Tahun).

\subsection{Keaktifan Lansia dalam Kegiatan Posyan- du Lansia}

Keaktifan lansia pada penelitian ini dapat dilihat dengan adanya rasa kebutuhan lansia untuk selalu hadir di posyandu. Selain itu keaktifan lansia menjadi satu ukuran betapa kuatnya motivasi lansia mengikuti posyandu.

Hasil wawancara dengan beberapa lansia menunjukkan bahwa peserta lansia sangat aktif mengikuti kegiatan posyandu lansia, mereka merasa seneng dan merasa rugi jika tidak hadir dalam kegiatan tersebut. Peserta posyandu lebih banyak perempuan hampir tiga kali lipat lebih. Berikut kutipan hasil indept interview peneliti ;

\section{Informan 1}

wah katah loh nak pesertanipun....remen sanget nak enten posyandu niku .....pikantuk obat, diprikso tensi...naming mbeto yotro kalih ewu.......katah rencangipun, saged geguyonan....ugi wonten gerak badane... seneng pokoke..rugi kulo yen mboten saged dateng ...pesertane katah perempuane (Tn H..65 tahun)

\section{Informan 2}

Posyandu lansia niku penting nak... ....engkang dateng katah thee......ten mriko seneng kok isoh amor koncone...isoh njoged-njoged entuk iburan......ono piknike barang...entuk obat...tak bela-belain teko nak rukun-rukun lansiane niku....(Ny S 59 tahun)

\section{Informan 3}

seneng enten posyandu lansia niku.., wonten periksa kesehatan ....... yo disana ada dikasih obat...dapat makan,... enten pengajiane juga......makanya diusahakan bisa berangkat ...hanya bawa uang dua ribu rupiah...bisa makan bersama.... malah enten piknik barang (Ny P, 57 Tahun)

\section{Informan 4}

Pesertanya seluruh lansia sini 115 orang......nanging mung tujuh puluhan niku seng pasti datang....tapi di sini paling seneng.. ada bakpak-pakanya juga ....kadere ramah-ramah.. wonten piknik ugi nem wulan sepindah (Ny S, 49 Tahun)

\subsection{Peran Kader dalam pelaksanaan kegiatan posyandu lansia.}

Hasil wawancara dengan beberapa informan kunci terkait peran kader dalam menggerakkan lansia di dapatkan data bahwa dalam melaksanakan posyandu lansia kader berupaya menambah kegiatan berupa pengajian, piknik dan pemberian makanan tambahan bukan dalam bentuk snak tapi makan bersama dengan menu yang sederhana misalkan soto dan lain. Namun PMT diberikan selang waktu tidak setiap bulan ada PMT. Selain itu jika ada anggota lansia tidak hadir berturut-turut kader berkunjung ke rumah lansia untuk menanyakan mengapa tidak datang. Dan jika ternyata sakit, maka kader bersamasama anggota lansia menengok dan mendoakan agar segera sembuh bisa bergabung lagi dengan lainnya. Untuk lebih jelasnya bisa dilihat pada kutipan hasil wawancara berikut.

Informan 1
Kadernya ramah-ramah dan rukun
bu....malah enten seng kakung......
kompaged nek nyiapne tip dingge senam seng
angkat junjung kakung.... kader nggeh
purun muruki ten griyone lansia diboncengke
buu.....yen enten seng mboten
dugi...dituenii......(Ny 56 Tahun)

\section{Informan}

bu.....malah enten seng kakung...... saged kompak nek nyiapne tip dingge senam seng angkat junjung kakung..... kader nggeh purun muruki ten griyone lansia diboncengke dugi...dituenii... ...(Ny 56 Tahun) 
PROFESI (Profesional Islam)

Media Publikasi Penelitian; 2017; Volume 15; No 1.

Website: ejournal.stikespku.ac.id

\section{Informan 2}

Kadere sregep kok buu.....nggeh kreatif ......kegiatane enten piknik ...enten lombane ugi........dados rame sanget kelompok posyandu mriki....yen enten seng mboten dugi dikunjungi kadere...(Ny A 54 tahun)

\section{Informan 3}

Wah ...jane kadere niku kirang bu...tapi semangatnya bagus bu...nggerakne masyarakat nggeh pantang menyerah...ngantos kegiatan posyandu mboten ngangge undangan cukup di woro-woro ten masjid bar subuhan niku....mengkeh mpun do dugi kiyambak.......kader nggeh purun turun ke warga ..... pados dana ten warga seng mampu.......(Tn H, 72 Tahun).

\subsection{Penggunaan KMS sebagai Alat Rekamedis Lansia}

Penggunaan KMS yang di posyandu lansia dari hasil wawancara menunjukkan bahwa KMS belum sepenuhnya digunakan untuk mencatat riwayat kesehatannya. Data yang dicatat pada KMS diposyandu desa Jetis adalah identitas lansia, berat badan dan tekanan darah. Hal tersebut dikarenakan kader jumlahnya terbatas dan kemampuan mengisi KMS juga kurang, bidan kewalahan melayani pemeriksaan karena lansia banyak. Selain itu kader merasa kesulitan membantu mengisi KMS karena tulisan di KMS kecil-kecil. Berikut hasil kutipan wawancara dengan beberapa informan kunci.

\section{Informan 1}

Mencatat KMS radi kesulitan mbak...tulisane cilik-cilik......yang dicatat nggeh berat badan dan tekanan darah....(Tn H. 72 tahun)

\section{Informan 2}

..yang dicatat tekanan darah dan berat badan....identitas jelas niku di KMS....tapi tulisannya kecil...(Ny S.49 tahun)

\section{Informan 3}

berat badan dan tekanan darah dicatat di KMS mbak....biar ndak lupa.....catatan perkembangan lainnya dereng soale lansianya banyak jadi radi kewalahan $(\mathrm{Ny}$ W. 35 tahun)

\subsection{Pelaksanaan Posyandu Lansia}

Penelitian ini menunjukkan bahwa alur pelayanan posyandu belum bisa dilakukan secara sistematis, namun jenis kegiatan yang diberikan untuk seluruh peserta posyandu sama yaitu pendaftaran, menimbang berat badan, mengukur tekanan darah, pemeriksaan oleh bidan sekaligus pemberian obat sederhana, senam lansia, pengajian dan PMT. Kegiatan posyandu desa Jetis ini bukan hanya menyangkut masalah pelayanan tentang kesehatan, namu ada pengembangan program yang menarik yaitu adanya senam lansia, pengajian, piknik dan PMT berupa makan bersama di posyandu. Penelitian ini sejalan dengan pernyataan yang dikemukankan oleh Kemenkes RI (2010) bahwa untuk menginisiatif seluruh lapisan masyarakat program posyandu lansia harus mempunyai inovasi baru dengan pendekatan social action.

\subsection{Keaktifan Lansia dalam Kegiatan Posyandu \\ Hasil penelitian ini menunjukkan bahwa} lansia di desa Jetis sangat aktif dan semangat mengikuti posyandu lansia. Penelitian ini mendukung penelitian Alvita (2014) bahwa lansia termotivasi untuk memanfaatkan posyandu lansia karena peran kader kesehatan yang aktif. Namun berbeda dengan penelitian Yunita \& Dewi (2012) yang dilakukan di Palembang serta Henniwati (2008) bahwa pemanfaatan posyandu lansia masih sangat rendah. Penelitian yang sama tentang pemanfaatan posyandu lansia yang dilakukan Fuad (2008) menjelaskan bahwa lansia senang menghadiri posyandu lansia karena senang bisa ketemu sesama lansia, tidak merasa kesepian.

Hasil penelitian membuktikan bahwa lansia peserta posyandu senang mengikuti kegiatan di posyandu salah satunya karena kader yang aktif menggerakkan masyarakat.

\subsection{Peran Kader Posyandu dalam Meng- gerakkan Posyandu Lansia}

Hasil penelitian membuktikan bahwa lansia peserta posyandu senang mengikuti kegiatan di posyandu salah satunya karena kader yang aktif menggerakkan masyarakat. Kader yang aktif dalam penelitian ini dengan penambahan kegiatan di posyandu serta adanya rasa keke- 
PROFESI (Profesional Islam)

Media PublikasiPenelitian; 2017; Volume 15; No 1.

Website: ejournal@stikespku.ac.id

luargaan yang kuat mampu memotivasi lansia dapat hadir di posyandu tersebut.

Penelitian ini mendukung penelitian yang telah dilakukan (Fatimah 2012, Anggraini et al 2015, Sasih et al 2015) yang menjelaskan bahwa peran kader mampu memotivasi para lansia untuk memanfaatkan posyandu lansia. Dan perilaku kader berhubungan dengan kunjungan posyandu lansia.

Ughniyatul (2016) juga menjelaskan bahwa peran kader kesehatan sangat kuat terbukti berhubungan dengan pemanfaatan posyandu lansia. Namun berbeda dengan Darmanto (2015) dalam penelitiannya menjelaskan bahwa peran kader kesehatan tidak berhubungan dengan keaktifan lansia dalam mengunjungi posyandu, namun lansia aktif ke posyandu karena pengetahuan dan dukungan keluarga.

\subsection{Penggunaan KMS}

Hasil wawancara tersebut menunjukkan bahwa KMS belum difungsikan secara optimal. KMS baru digunakan untuk mencatat berat badan dan tekanan darah. Sedangkan Subijanto et al (2011) menjelaskan bahwa posyandu lansia secara ideal dilakukan dengan sistem lima meja. Meja ketiga adalah pelaksanaan pencatatan hasil pengukuran Indeks massa tubuh, berat badan, tinggi badan dan tekanan darah. Pencatatan tersebut idealnya dilakukan di KMS sehingga bisa terpantau riwayat kesehatn lansia dengan baik. Karena memang fungsi KMS adalah sebagai alat rekamedis (medical record).

Tidak difungsikannya KMS sesuai harapan tersebut karena merasa terbatasnya jumlah kader dan terbatasnya kemampuan dalam mengisi KMS serta merasa formatnya kekecilan, tulisan tidak kelihatan.

\section{SIMPULAN}

Berdasarkan hasil penelitian yang telah dipaparkan, maka dapat disimpulkan bahwa 1) sistem pelayanan posyandu lansia belum berjalan dengan baik seperti lima meja yang ditetapkan dari puskesmas, 2) Lansia desa Jetis sangat aktif dan senang mengikuti kegiatan posyandu, 3) kader posyandu sangat aktif dengan bentuk kegiatannya mencari dana, menjemput lansia yang tidak bisa hadir karena tidak ada kendaraan, membuat kreatifitas kegiatan yang menarik seperti piknik, pengajian, makan bersama, 4) KMS belum dimanfaatkan secara maksimal.

\section{REFERENSI}

Alvita, GW. 2014. Hubungan dukungan social dengan pemanfaatan posyandu lansia di desa Karangmulyo Kecamatan Tambak kromo Pati, Jurnal Keperawatan dan kesehatan masyarakat Cendekia Utama, Vol 2.(3) p 1

Anggraini, D., Zulpadiana, Mulyanti. 2015. Faktor Dominan Lansia Aktif Mengikuti Kegiatan Posyandu di Dusun Ngentak. JNKI, Vol. 3, No. 3, p 150-155

Darmanto, J Arneliwati, Woferst R. 2015. Hubungan Kinerja kader Posyandu dengan Motivasi Lansia mengunjungi Posyandu lansia, Jom, vol 2. 1

Depkes RI. 2003. Pedoman Pengelolaan Kegiatan Kesehatan di Kelompok Usia Lanjut. Dirjen Bina Kesehatan Masyarakat DEPKES RI. Jakarta

Dinas Kesehatan Propinsi. 2012. Profile Dinas Kesehatan Propinsi Jawa Tengah

Fatimah. 2012. Peningkatan Pengetahuan dan Ketrampilan Kader Posyandu Dalam Pengukuran Tinggi badan Prediksi Lansia Penyuluhan Gizi Seimbang dan Hipertensi Studi di Kecamatan Grogol Petamburan Jakarta barat, Jurnal diakses dari http://www.ejournal.undip.ac.id/index.php/m mi/articlrahayue/view/4218/3844

Fuad. 2008. Study fenomenology Motivasi Lansia Dalam Memanfaatkan Karanganyar. Program Study Ilmu Keperawatan FK Universitas Diponegoro.

Heniwati. 2008. Faktor-faktor yang mempengaruhi pemanfaatan pelayanan posyandu lanjut usia di wilayah kerja puskesmas kabupaten Aceh Timur (online. http://repository.usu.ac.id/bitstrem/12345678 9/6745/1/08E00905.pdf. 
PROFESI (Profesional Islam)

Media Publikasi Penelitian; 2017; Volume 15; No 1.

Website: ejournal.stikespku.ac.id

Ismawati, C. 2010. Posyandu dan Desa Siaga Panduan untuk Bidan dan Kader. Yogyakarta, Nuha Medika

Kemenkes R.I. 2010. Buku Panduan Kader Posyandu. (Edisi ke I). Jakarta

Kementrian Kesehatan, R.I. 2013. Pedoman Pengelolaan Posyandu. Depkes R.I

Notoatmodjo, S. 2007. Kesehatan Masyarakat Ilmu dan Seni, Rineka Cipta, Jakarta

Sasih, NM., Hadi, M., Tandipanjung, T. 2015. Hubungan Peran Kader dengan Motivasi lansia mengikuti Posyandu di Kalurahan Apla I Kecamatan Ranowulu Bitung, EJurnal Sariputra, vol 2.p. 2
Subijanto., Redono, D., Vendarani,V.F. 2011. Modul KIE,Pembinaan Posyandu Lansia Guna Pelayanan Kesehatan Lansia, Fakultas Kedokteran Uiversitas Negeri Surakarta.

Ughniyatul M. 2016. Hubungan peran kader dengan keaktifan kunjungan posyandu lansia di Wilayah kerja puskesmas Godean, ETD UGM,

II.http://etd.repository.ugm.ac.id/index.php? act=view\&buku_id=97510\&mod=penelitian _detail\&sub=PenelitianDetail\&typ=html

Yuniati \& Dewi. 2012. Pemanfaatan Posyandu Lanjut Usia (online) http://jurnal.poltekkes palembang.ac.id/wp 